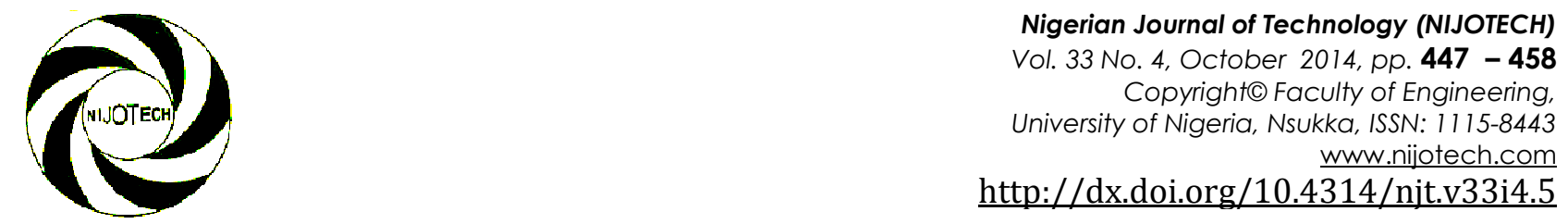

\title{
STRESS DISTRIBUTION IN CONTINUOUS THIN-WALLED MULTI-CELL BOX GIRDER BRIDGES
}

\author{
G. C. Ezeokpube ${ }^{1, *}$ and N. N. Osadebe ${ }^{2}$ \\ 1 DEPARTMENT OF CIVIL ENGinEeRING, MichaEl OKPARA UNIVERSITY OF AGRICULTURE, UMUdiKE, NIGERIA \\ 2 DEPARTMENT OF CiVIL ENGINEERING, UNIVERSITY OF NigERIA NSUKKA, NIGERIA \\ E-mail addresses:1 engrgreg2006@yahoo.com,2mkemamaka@yahoo.com
}

\begin{abstract}
Several researchers have studied stresses in thin-walled box girder bridges but stress distribution in continuous thin-walled multi-cell box girder bridges has not received much attention in published literature. Hence, this research investigated stress distribution in continuous thin-walled multi-cell box girder bridges. Analysis of box girder bridges is complex and the complexity is even more when the box girder is continuous with multi-cells. The modern trend in the analysis is to program the more straightforward methods for ease of computer application. Therefore, the analytical tool for this study is a MATLAB program developed by the authors for the finite strip analysis of continuous thin-walled box girder bridges. Numerical study on stress distribution was carried out on two box girder bridges. The first was a simply supported box girder bridge subjected to eight point loads which was used primarily for comparison with literature. The result obtained by the program was in good agreement with literature. The second was a continuous thin-walled multi-cell box girder bridge subjected to vehicular loads and self weight. The beam theory solution was also used for comparison of results in both cases. The study concluded that under symmetrical loading the longitudinal normal stress, shear stress at end supports, transverse bending moment, and longitudinal bending moment are substantial while the transverse normal stress and twisting moment are negligible. The program can, therefore, be used in practice to determine stress distributions of box girders and prismatic folded plates. However, classical finite strip underestimates stress values at points of high stress concentration.
\end{abstract}

Keywords: stress distribution; continuous bridges; thin-walled multi-cell; box girder bridges; finite strip method.

\section{INTRODUCTION}

The most popular type of highway bridge in service is the concrete deck on steel-girder bridge [8]. However, this type of concrete bridge was not economical for long spans because of the rapid increase in the ratio of dead to total design load as the span lengths increased and so the box girder bridge, with hollow sections, was developed as a solution to the problem. High torsional resistance, economy of thin-walled members, and aesthetics are additional qualities that make the box girder bridge a popular choice. Box girder bridges are common in the western world especially California [17].

A box girder bridge is a particular case of a foldedplate structure in which the plates are arranged so as to form a closed section [5, 14]. Box girder configurations may take the form of single cell (one box), multispine (separate boxes), or multicell (contiguous boxes or cellular shape) with common flange $[4,16]$. A typical cross-section of reinforced or prestressed concrete multicell box Girder Bridge consists of top and bottom slab (or flange) connected monolithically by vertical webs (or stem) to form a cellular or box-like structure.

Analytically, however, thin-walled box girder bridge has proved to be a very complex indeterminate problem. Fundamental contributions to the general solutions were given by Vlasov [18]. Since then, a lot of analytical and experimental studies on the static, dynamic, and stability analyses of thin-walled box girders has been presented in journals by many other researchers.

Several studies have been presented on stresses in thin-walled box girder bridges. Luo et al. [12] 
proposed a new approach for the calculation of moments on top slab in single-cell box girders, using the classical thin plate theory and trigonometric series. Lertsima et al.[11] investigated the stress concentration in a flange due to shear lag in simply supported box girder by the three-dimensional finite element method using shell elements. Sanguanmanasak et al. [15] presented a study on stress concentration due to shear lag in continuous singlecell box girders while Yamaguchi [19] presented a research study on stress concentration and deflection of simply supported box girder including shear lag effect. Halkude and Akim [9] presented a study on the analysis of simply supported straight and skewed box girder bridge by the finite strip method. The study concluded that the longitudinal bending moment decreases and the twisting moments increase with the skew angle.

Based on available literature, stress distribution in continuous thin-walled multi-cell box girder bridges has not received much attention and much research work has not been presented in the application of MATLAB software to the analysis of box girder bridges. Therefore, this research study is concerned with stress distribution in continuous thin-walled multi-cell box girder bridges. The Finite Strip Method is considered very suitable for the present study and MATLAB is considered the software of choice. The analytical tool for this research is a MATLAB Computer program for the finite strip analysis of continuous thin-walled box girder bridges including the effects of shear deformation. The development and validation of this program were performed by the authors [6].

\section{THE FINITE STRIP METHOD}

The finite strip method (FSM) can be considered as a kind of finite element method (FEM) in which a special element called the strip is used [13]. FSM can, therefore, be regarded as a degenerate form of FEM which is used to primarily model the response of prism-like structures such as plates and solids (M.S. Cheung et al., 1996). The aim of FSM is not to replace entirely the FEM but compliment it where FSM is more effectively used for the analysis of structures with geometry of a large length in the longitudinal direction and relatively short transverse length such as box-girder bridges [3]. For bridges having regular geometric plans and simple boundary conditions, a full finite element analysis is often both extravagant and unnecessary [9]. The cost of solution can be high and usually jumps by an order of magnitude when a more refined higher dimensional analysis is required [2]. While FEM usually requires large quantities of input data and thus more chances to make mistakes, the process of analysis and input handling used in FSM are very simple and convenient [3]. The flat shell strip was employed in this analytical study.

\section{STRUCTURAL RESPONSES}

A complicated state of responses develops when a box girder bridge is loaded particularly when the bridge is curved. However, using the flat shell strip the following responses are considered: (1) deflection $\omega$, (2) in-plane transverse displacement $u$, (3) in-plane longitudinal displacement $v$, (4) transverse bending moment $M_{x}$, (5) longitudinal bending moment $M_{y}$, (6) twisting moment $M_{x y}$, (7) transverse normal stress $\sigma_{x}$, (8) longitudinal normal stress $\sigma_{y}$, and (9) shear stress $\tau_{x y}$.

\section{SIGNIFICANCE OF THE STUDY}

Although box girder bridges are not common in Nigeria, it is believed that they may offer economic advantages in future high way projects in Nigeria where the slab-on-girder bridges dominate the highway systems. The federal government policy on dredging of major rivers in the country will be more profitable with the introduction of long span bridges like the box girder bridge because passage of bigger and wider vessels (ships), under such bridges, will be permitted. Additionally the hollow sections of such box girder bridges could be used to accommodate services such as public utilities and drainage systems. Box sections can provide stability for long span bridges and allow large deck overhangs. The closed box section in the completed bridge has a torsion stiffness that may be 100 times to more than 1000 times the stiffness of a comparable I-girder section [7]. Also the inherent torsional rigidity of curved steel boxes permit shipping and erecting without external supports.

\section{METHODOLOGY}

Using the MATLAB program for the finite strip analysis of continuous thin-walled box girder bridges, numerical studies on stress distributions was carried out on two box girder bridges, namely: (1) a simply supported thin-walled box girder bridge, and (2) a continuous thin-walled multi-cell box girder bridge. Analytical results for the simply supported thinwalled box girder bridge were for comparison with 
literature after which a more detailed analysis were carried out to study stress distribution in the continuous multi-cell box girder. The beam theory solutions were also presented for both structures for comparison with the finite strip solutions. Analytical results were presented in the form of plots and tables. Useful inferences were made from the results of analyses.

\section{GENERATING A FINITE STRIP MODEL}

In using the classical finite strip method the following modeling provided adequate accuracy:

- The flanges and webs are idealized as the orthotropic plates with equivalent elastic properties.

- Each end support of the bridge is assumed to be a diaphragm which is infinitely stiff in its own plane but infinitely flexible out of plane. There could be also diaphragms over intermediate supports.

- Intermediate supports can be simulated by the application of eigenfunctions of the continuous beam using a stiffness approach.

- A finite strip spans between two opposite end supports. Each web is divided into one to three strips. The flange in each cell or overhang is divided into two to five strips. If more accurate results are desired for the in-plane shear stress and for the transverse bending moment more strips should be used.

- It is advisable to start with a course mesh. Then refine the modeling and improve the accuracy step by step until convergence occurs.

- Each wheel load should acts on a nodal line. A nearby nodal line is moved to the application point of the load or an additional nodal line is added underneath the load if necessary.

- In regions with a higher stress gradient, narrower strips should be used. The width of the strip should change gradually from one strip to another.

- If the cross-section and loads are both symmetrical about the centerline only half of the bridge needs to be analyzed.

\section{ALGORITHM OF THE MAIN ANALYSIS} Step (1): Read Data

Read data on strip properties, material properties, integration values, series terms and boundary conditions.

\section{Step (2): Global Stiffness Matrix}

For each series term, calculate global stiffness matrices of the strips using flat shell strip and assemble the global structure stiffness matrix

\section{Step (3): Global Load Vector}

For each series term, calculate the global load vector for the strips and assemble the global structure load vector

\section{Step (4): Equilibrium Equation}

Formulate the equilibrium equation for each series term by equating the global structure stiffness matrix to the global structure load vector.

$$
[\mathrm{K}]_{\mathrm{tmn}}\{\delta\}_{t m}=\{F\}_{t m}
$$

In (1), $[\mathrm{K}]_{\mathrm{tmn}}$ is the global stiffness matrix, $\{\delta\}_{t m}$ is the global stiffness vector and $\{F\}_{t m}$ is the global structure load vector.

\section{Step (5): Application of Boundary Conditions}

Apply boundary conditions to the equilibrium equation to obtain a reduced equilibrium equation which is of the form

$$
\left[\mathrm{K}_{\mathrm{r}}\right]_{\mathrm{tmn}}\left\{\delta_{r}\right\}_{t m}=\left\{F_{r}\right\}_{t m}
$$

In (2), $\left[\mathrm{K}_{\mathrm{r}}\right]_{\mathrm{tmn}}$ is the reduced global stiffness matrix, $\left\{\delta_{r}\right\}_{t m}$ is the reduced global displacement vector and $\left\{F_{r}\right\}_{t m}$ is the reduced global structure load vector.

\section{Step (6): Solve the Reduced Equilibrium Equation}

Solve the set of equilibrium equation of the structure to obtain the structure displacement amplitudes.

\section{Step (7): Post-processing}

Interpolate for bending and in-plane actions using local displacement amplitudes.

\section{NUMERICAL EXAMPLE 1: SIMPLY SUPPORTED THIN-WALLED BOX GIRDER BRIDGE}

\subsection{Bridge Description, Loading and Finite Strip Model}

A simply supported concrete box girder bridge with span $\mathrm{L}=40 \mathrm{~m}$ is subjected to self-weight and eight point forces, which are symmetrical about the midspan and centerline of cross-section and have magnitude $50 \mathrm{kN}$ each, as shown in Figures. 1 and 2. The cross-section has a top flange of thickness $0.3 \mathrm{~m}$, a bottom flange of thickness $0.5 \mathrm{~m}$ and two webs of thickness $0.4 \mathrm{~m}$. The material properties are $\mathrm{E}=30000 \mathrm{Mpa}$ and $v=0.15 . \quad$ The density, is $\gamma=24 \mathrm{kNm}^{-3}$. The finite strip model is shown in Figure 3. 


\subsection{Comparison of Analysis Results with Literature}

The results obtained with the program are compared with that of Cheung et. al. [1]. The transverse bending moment distribution obtained by using the program are exactly the same with that of Cheung et al. [1], as shown in Figure 5. However, minor differences exist in the longitudinal normal stress distribution (Figure 4) in which case the results in parentheses are those of Cheung et. al. [1].

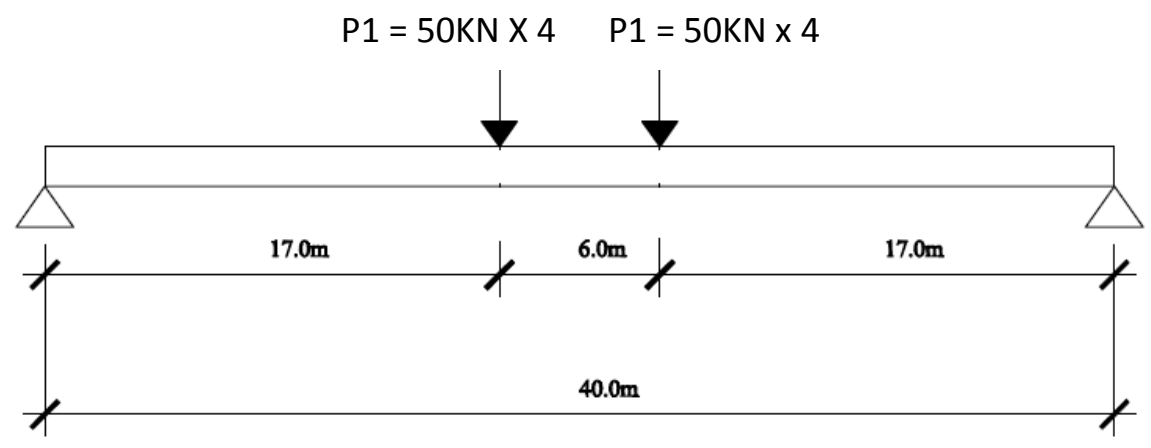

Figure 1 Longitudinal Section of simply supported Box Girder Bridge
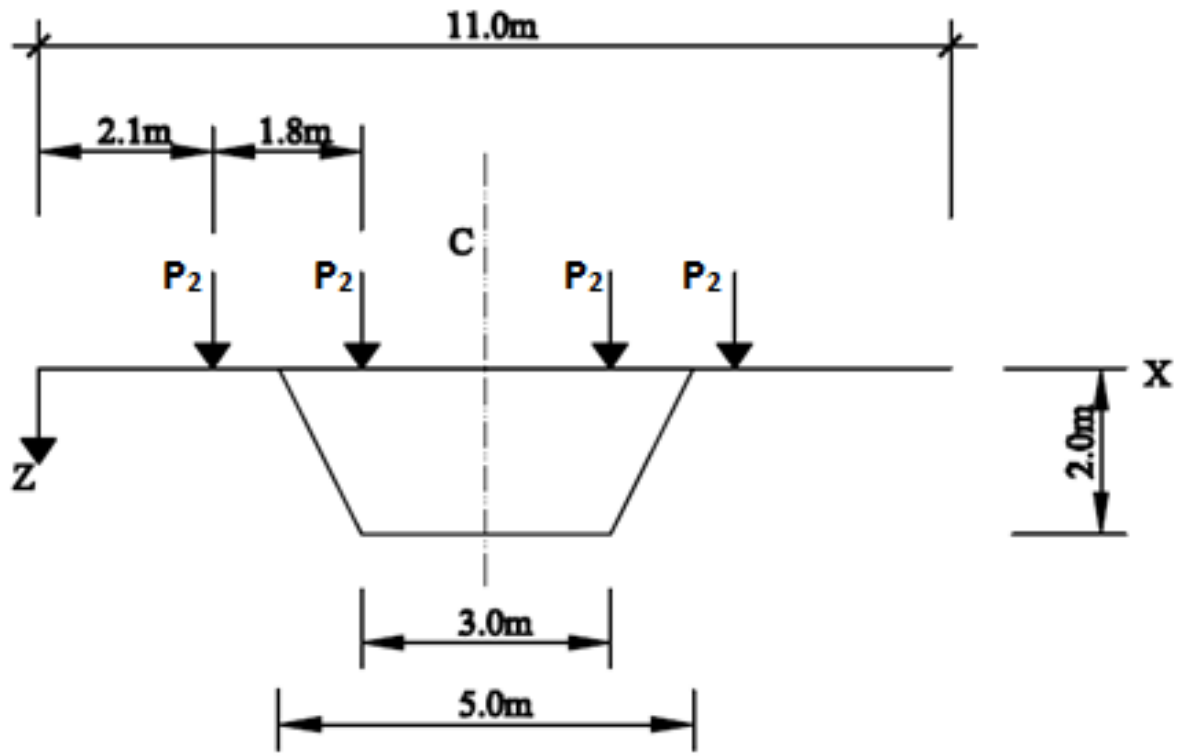

Figure 2: Cross Section of simply supported Box Girder Bridge

$$
\mathrm{P} 2=50 \mathrm{KN} \times 2 \quad \mathrm{P} 2=50 \mathrm{KN} \times 2
$$

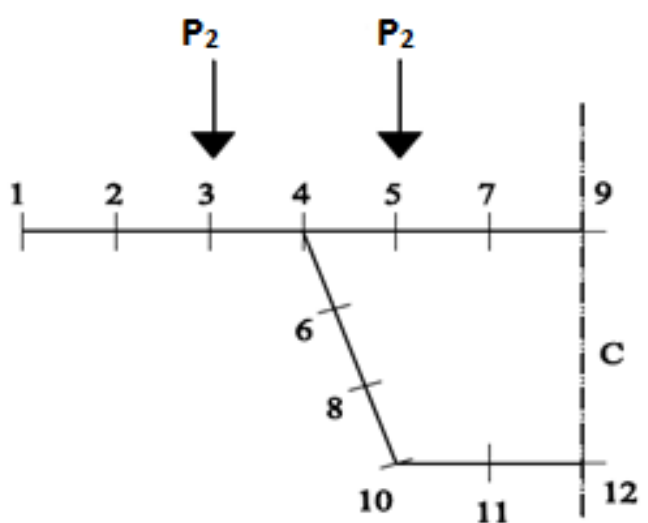

Figure 3: The Finite Strip Model (11 Strips) showing Nodal Lines for symmetrical half of the bridge

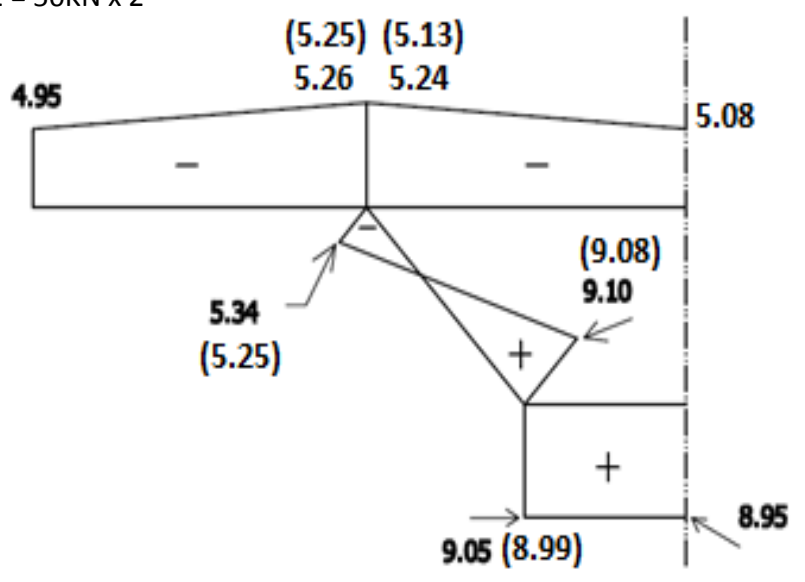

Figure 4 Longitudinal Normal Stress (MPa) 


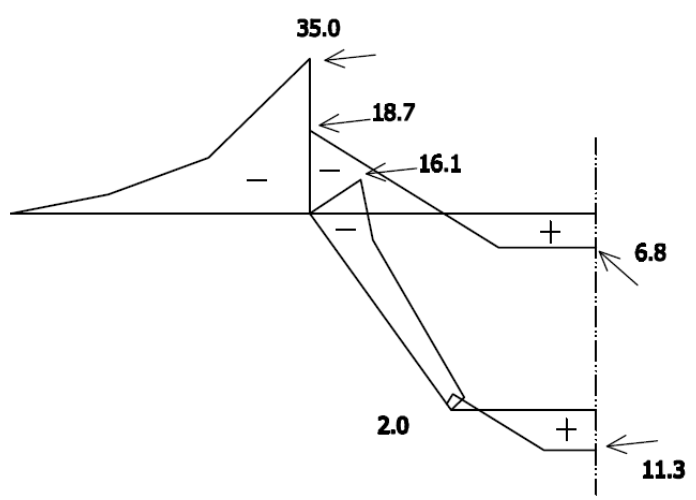

Figure 5 Transverse Bending Moment $(\mathrm{kNm} / \mathrm{m})$

\section{NUMERICAL EXAMPLE 2 - CONTINUOUS THIN- WALLED MULTI-CELL BOX GIRDER BRIDGE}

\subsection{Bridge Description and Loading}

The bridge model (Figures $6-8$ ) is a thin-walled fourlane reinforced concrete box girder bridge which is continuous over two supports with simply supported ends. An equal length of $50 \mathrm{~m}$ is used for each span. The outer webs are inclined while the inner webs are normal to the top and bottom flanges. Top flanges are cantilevered. Economy and aesthetics lead to the evolution of cantilevering of top flanges and provisions of inclined webs for extreme cells. A typical cross-section of the bridge along with the wheel loads is shown in Figure 8. Using the thin-walled crosssection theory [10], the following ratios are chosen for the dimensions of the Bridge:

$$
\frac{\text { Thickness of Web }}{\text { Depth of Web }}=\frac{1}{8}<\frac{1}{7}
$$

$$
\begin{gathered}
\frac{\text { Thickness of Flange }}{\text { Width of Flange }}=\frac{1}{12.2}<\frac{1}{10}, \\
\frac{\text { Overall Depth of Cross Section }}{\text { Span Length }}=\frac{1}{25}<\frac{1}{10}, \\
\frac{\text { Width of Flange between adjacent Webs }}{\text { Overall Depth of Cross Section }} \\
=1.83 \text { (close to } 2)
\end{gathered}
$$

At the middle span (see Figures 6 and 7), each lane of the bridge was subjected to two standard AASHTO HS25 design vehicle. In all, a total of eight vehicles are distributed symmetrically at the middle span of the four-lane bridge. In addition all spans are subjected to self weight of the bridge. It is required to carry out a finite strip analysis of the bridge for the stress distribution. For symmetry, only half the bridge is analyzed.E $=30 \times 10^{6} \mathrm{kNm}^{-2}, v=0.15, \Upsilon=$ $24 \mathrm{kNm}^{-3}$.

\subsection{Finite Strip Model}

After a convergence test involving three models in which the symmetrical half of the bridge were subdivided into 19, 27, and 35 finite strips in each case, the model with 35 finite strips was chosen for the analytical study. The chosen model shall, simply, be referred to as the finite strip model for this research work. The properties of the finite strip model are shown in Figure 9.

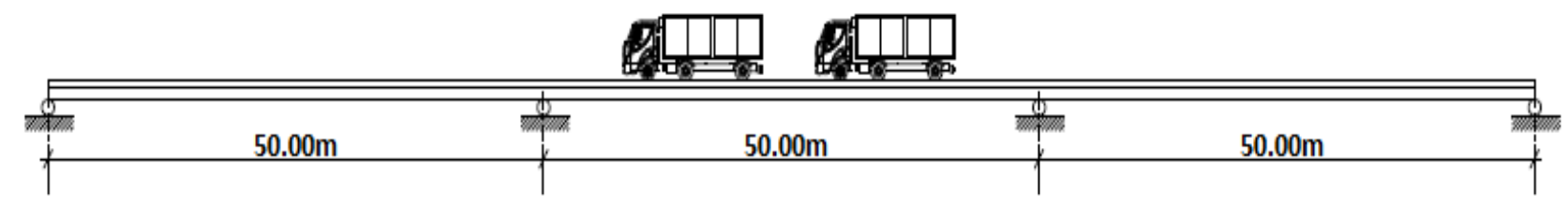

Figure 6: Longitudinal Section of the Three-Span Four-Cell Continuous Box Girder Bridge Subjected to Self-Weight and Vehicular Load (AASHTO-25 TRUCK)

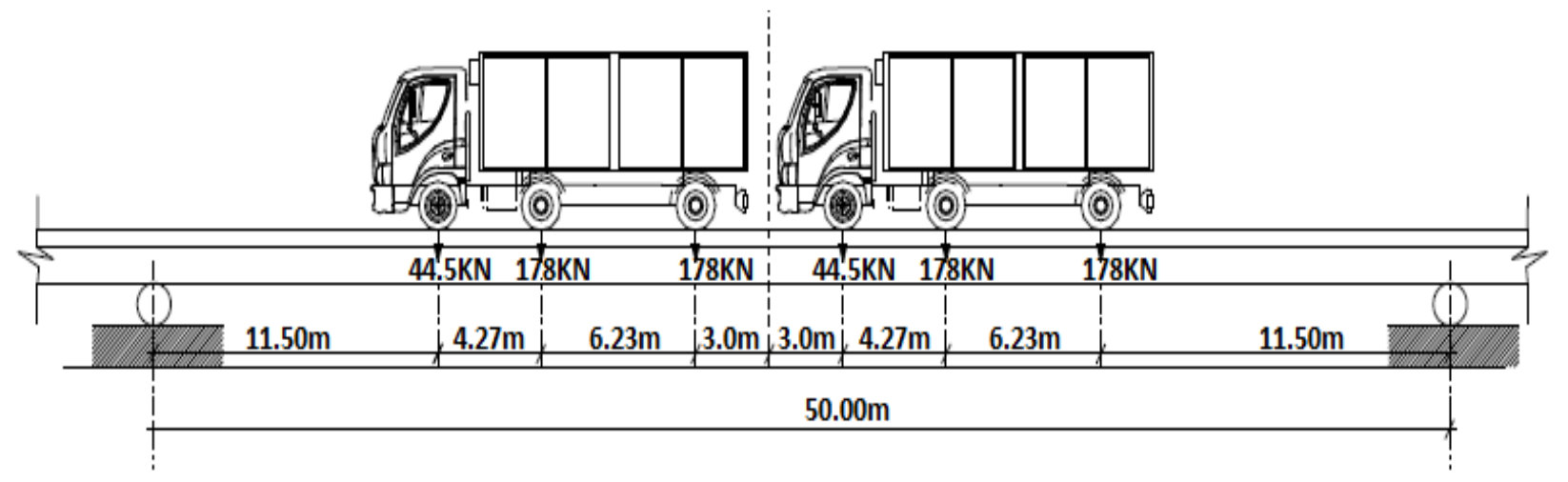

Figure 7: Longitudinal Section of Mid-Span Showing Axle Loads 


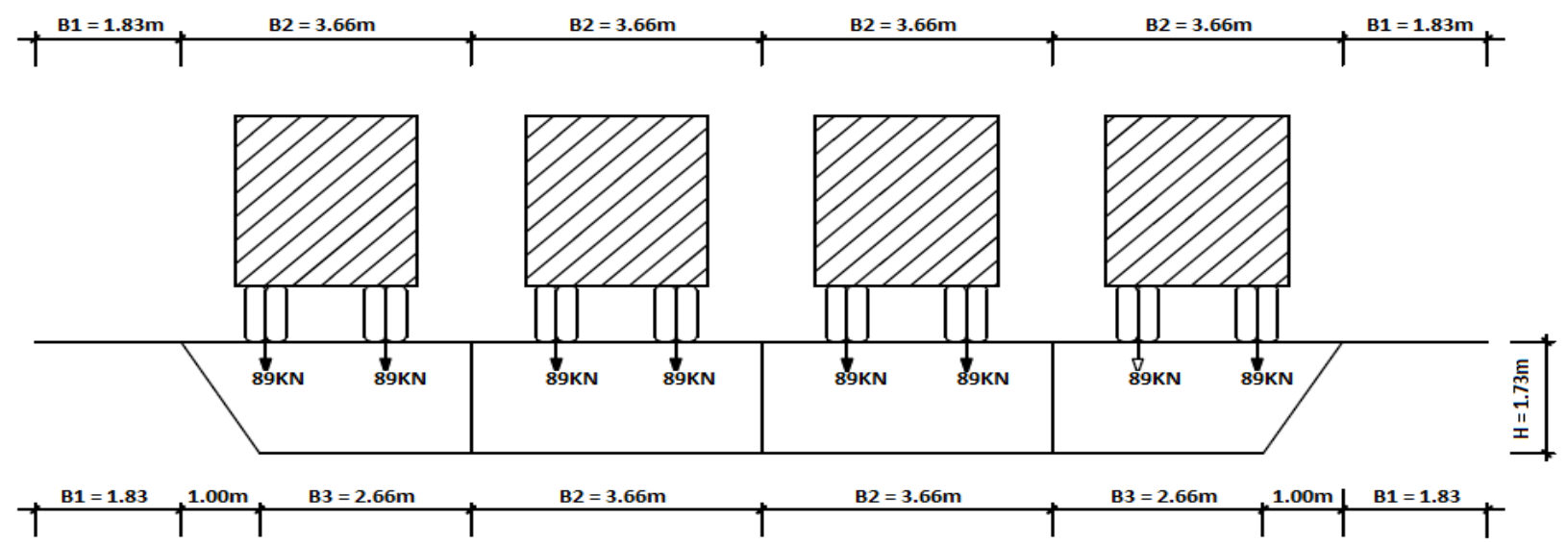

Figure 8: Cross-Section of the Three-Span Four-Lane Continuous Box Girder Bridge showing wheel loads

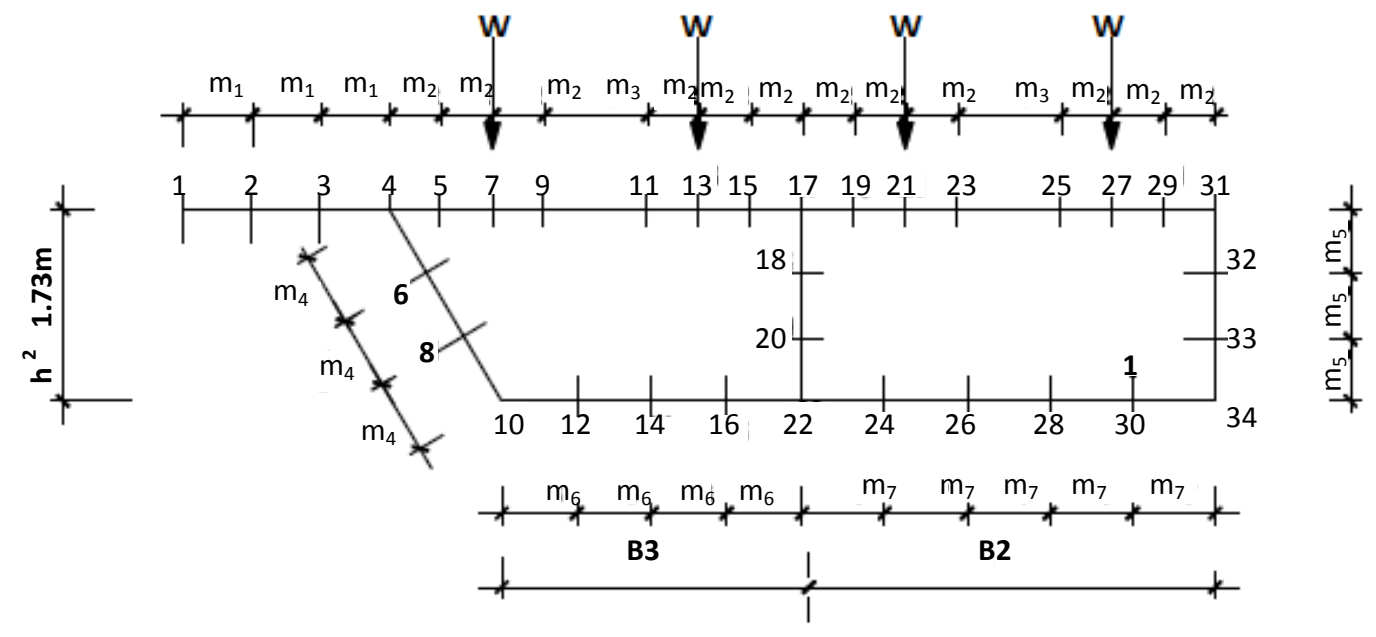

Figure 9: The Finite Strip Model (35 strips): Cross-section showing Nodal Lines for symmetrical half of the bridge

A

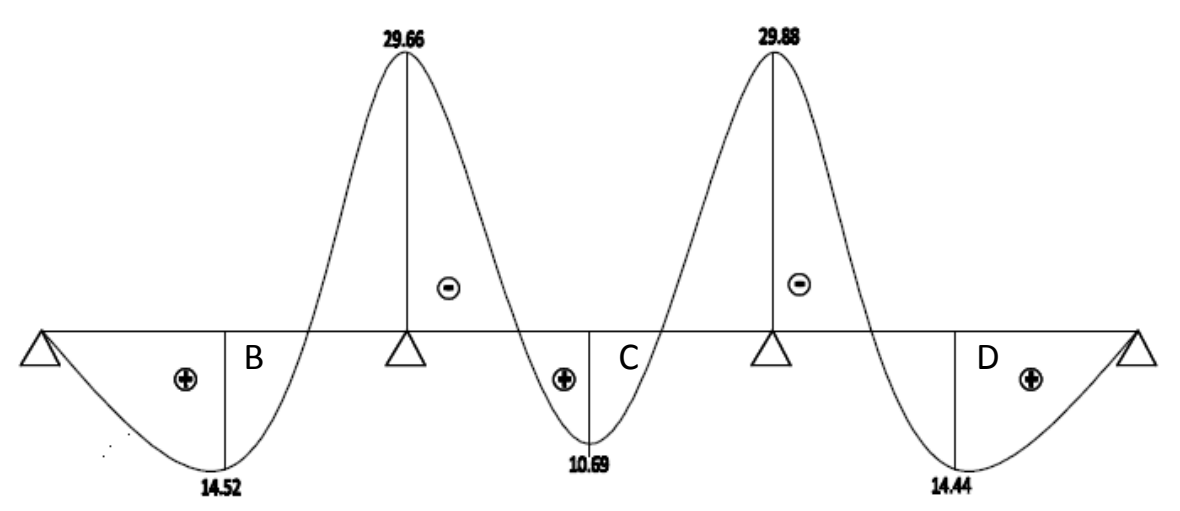

Figure 10: Longitudinal Distribution of Longitudinal Bending Moment (kNm/m) at Top Flange along Bridge Centerline 
A

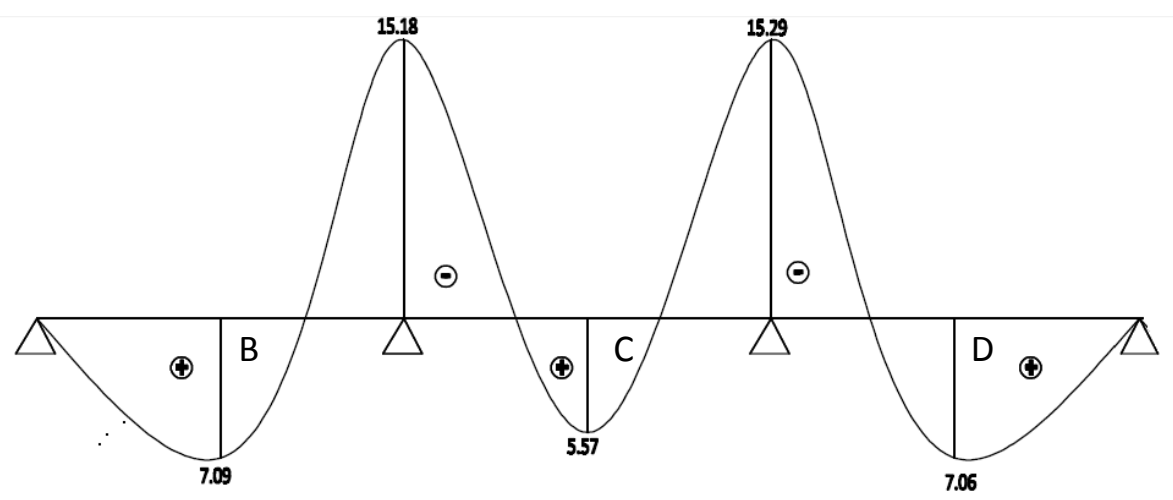

Figure 11: Longitudinal Distribution of Longitudinal Bending Moment $(\mathrm{kNm} / \mathrm{m})$ at Bottom Flange along Bridge Centerline

A

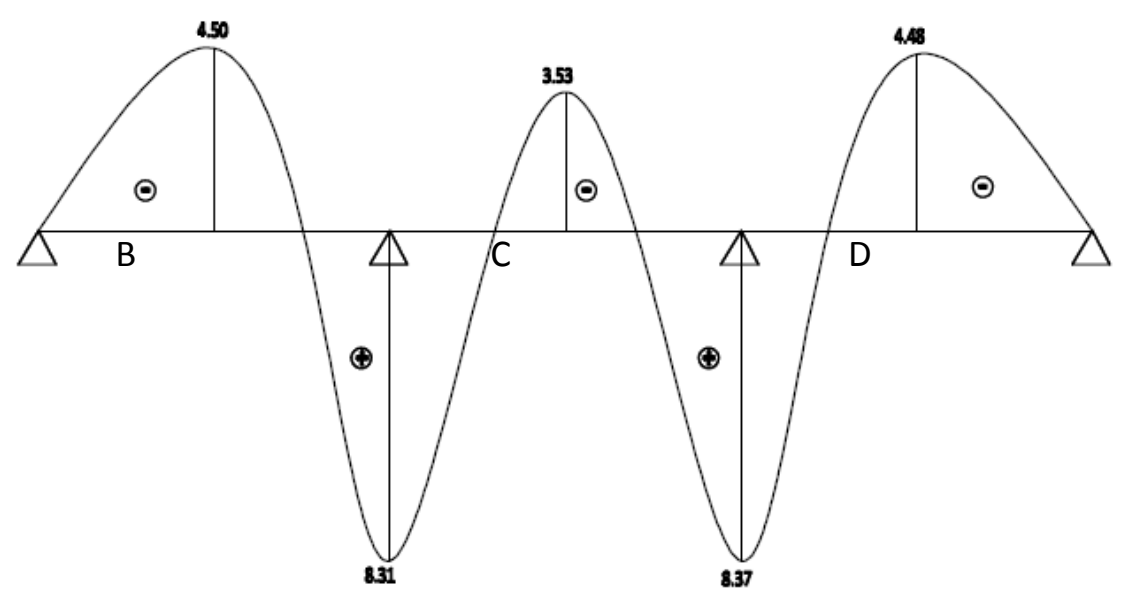

Figure 12: Longitudinal Distribution of Longitudinal Normal Stress (MPa) at Top Flange along Bridge Centerline

A

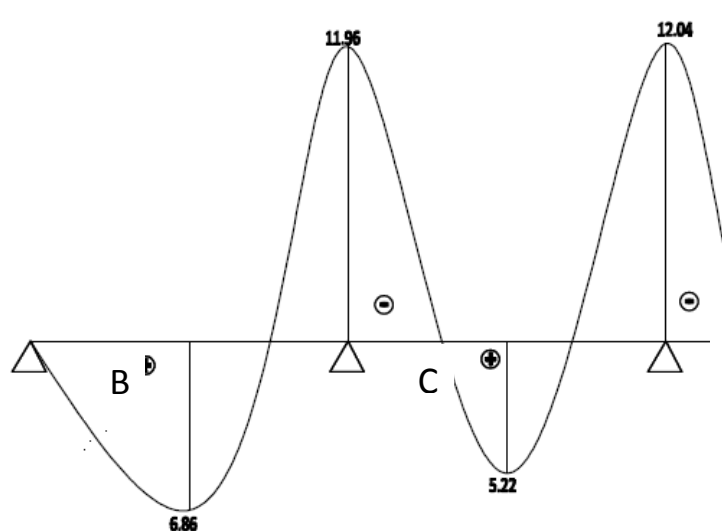

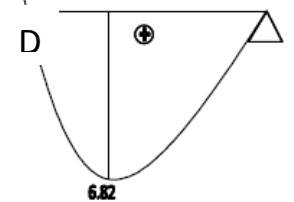

Figure 13: Longitudinal Distribution of Longitudinal Normal Stress (MPa) at Bottom Flange along Bridge Centerline 


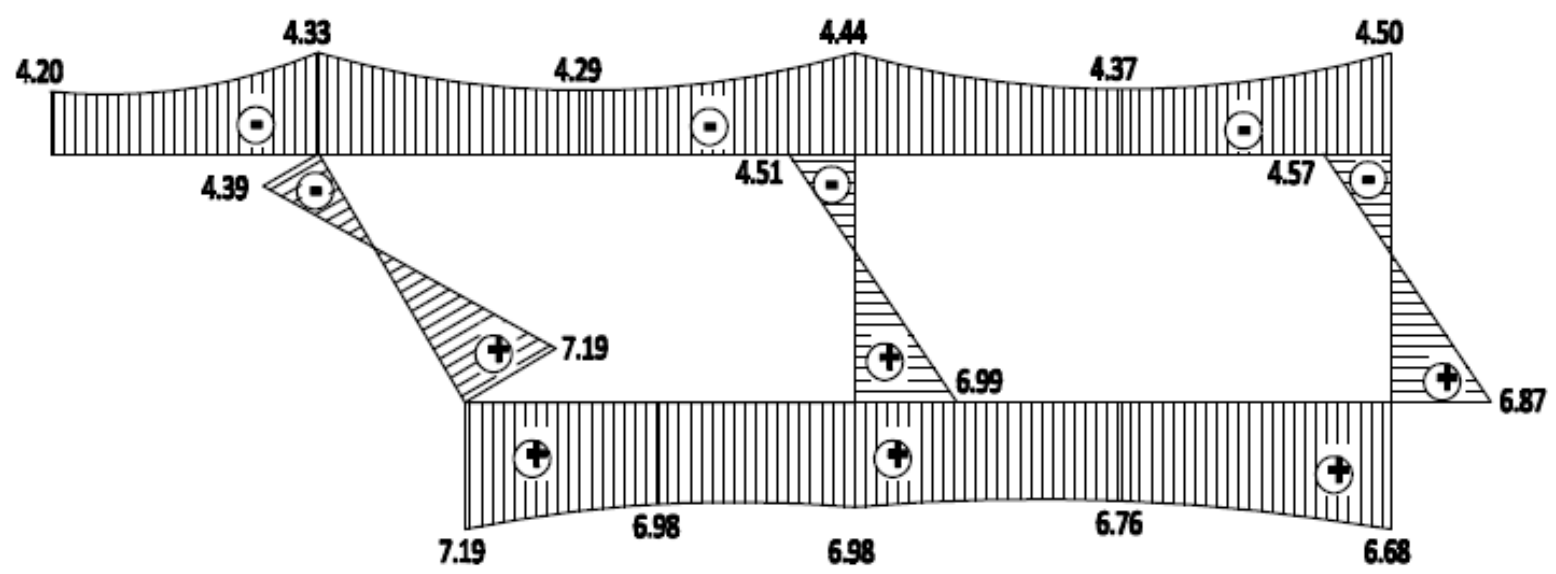

Figure 14: Transverse Distribution of Longitudinal Normal Stress (MPa) at Cross-Section through the Mid-Point of 1st $^{\text {s }}$ Span

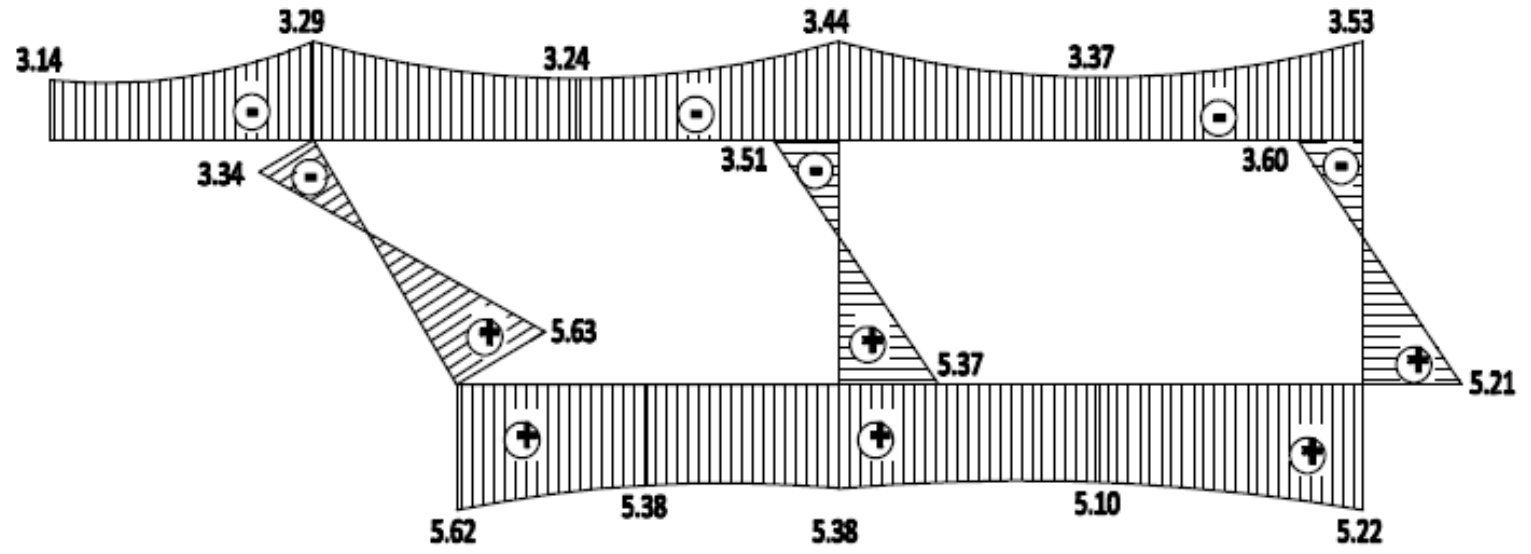

Figure 15: Transverse Distribution of Longitudinal Normal Stress (MPa) at Cross-Section through the Mid-Point of $2^{\text {nd }}$ Span

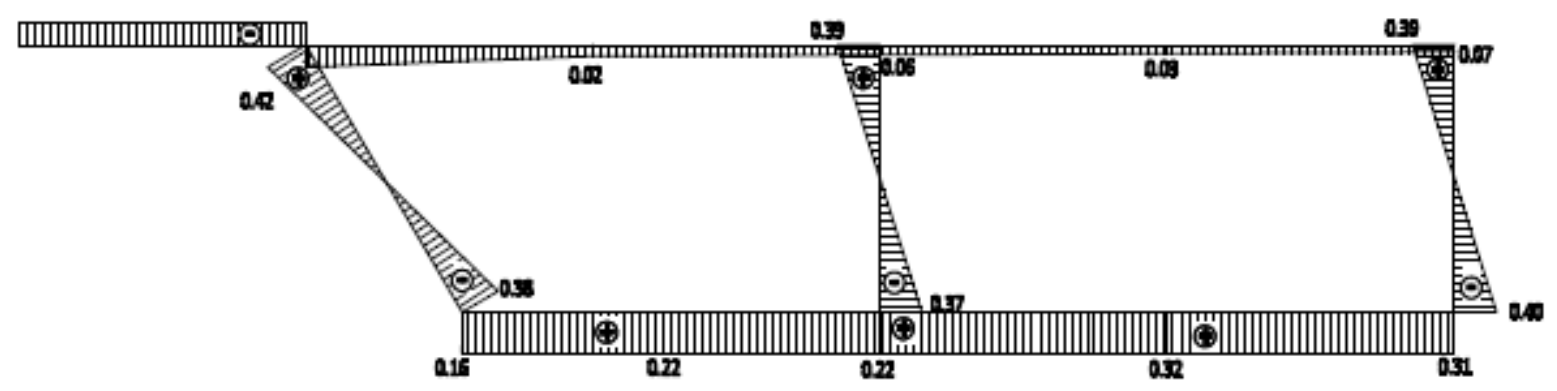

Figure 16: Transverse Distribution of Transverse Normal Stress (MPa) at Cross-Section through the Mid-Point of $1^{\text {st }}$ Span 


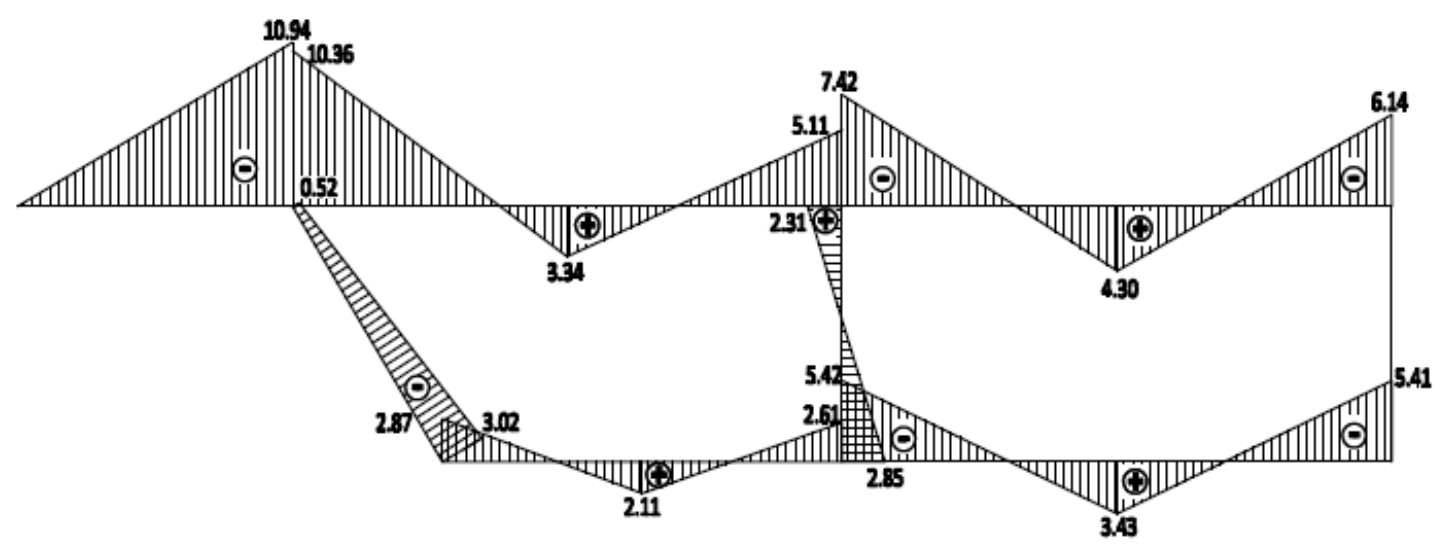

Figure 17: Transverse Distribution of Transverse Bending Moment $(\mathrm{kNm} / \mathrm{m})$ at Cross-Section through the Mid-Point of $1^{\text {st }}$ Span

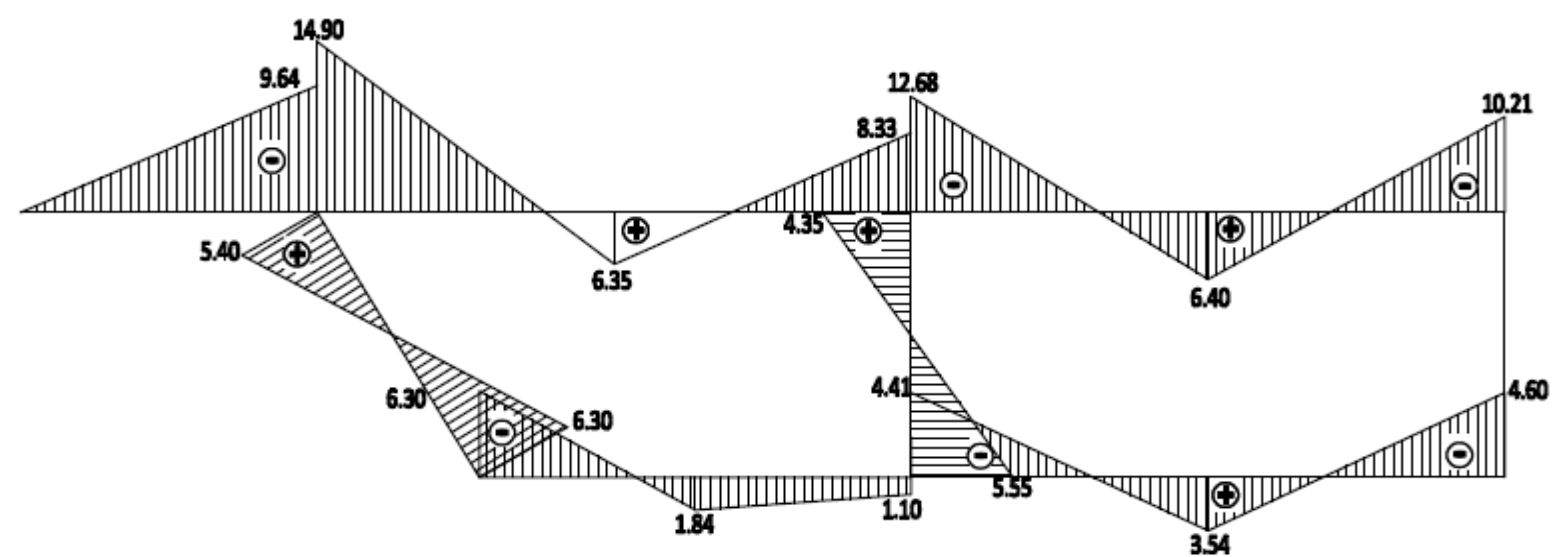

Figure 18: Transverse Distribution of Transverse Bending Moment $(\mathrm{kNm} / \mathrm{m})$ at Cross-Section through the Mid-Point of 2nd Span

Table 1: Shear Stress Distribution in Webs (MPa)

\begin{tabular}{|c|c|c|c|c|c|c|c|c|c|}
\hline \multirow[b]{2}{*}{$\begin{array}{c}\text { Type of } \\
\text { Web }\end{array}$} & \multirow[b]{2}{*}{ Remark } & \multirow[b]{2}{*}{$\begin{array}{c}\text { Vertical } \\
\text { Ordinate } \\
\text { z(m) }\end{array}$} & \multirow{2}{*}{$\frac{1}{1^{\text {st }}}$} & \multirow[b]{2}{*}{$\begin{array}{c}2 \\
\text { Mid- } \\
\text { span of } \\
1^{\text {st }} \\
\text { Span }\end{array}$} & \multirow{2}{*}{$\begin{array}{c}3 \\
2^{\text {nd }} \\
\text { support }\end{array}$} & \multirow[b]{2}{*}{$\begin{array}{c}4 \\
\text { Mid- } \\
\text { span of } \\
2^{\text {nd }} \\
\text { span }\end{array}$} & \multirow{2}{*}{$\begin{array}{c}5 \\
3 r d \\
\text { support }\end{array}$} & \multirow[b]{2}{*}{$\begin{array}{c}6 \\
\text { Mid- } \\
\text { span of } \\
3^{\text {rd }} \\
\text { span }\end{array}$} & \multirow{2}{*}{$\begin{array}{l}7^{\text {th }} \\
\text { support }\end{array}$} \\
\hline & & & & & & & & & \\
\hline & Top & 0.00 & 2.772 & -0.591 & 0.323 & -0.004 & -0.357 & 0.594 & -2.762 \\
\hline & --- & 0.58 & 2.771 & -0.592 & 0.323 & -0.003 & -0.357 & 0.595 & -2.761 \\
\hline Exterior & $*$ & 0.67 & 2.821 & -0.603 & 0.328 & -0.004 & -0.362 & 0.606 & -2.811 \\
\hline \multirow[t]{4}{*}{ Web } & $* *$ & 0.87 & 2.817 & -0.603 & 0.328 & -0.003 & -0.362 & 0.606 & -2.808 \\
\hline & --- & 1.15 & 2.474 & -0.532 & 0.279 & -0.002 & -0.308 & 0.534 & -2.465 \\
\hline & Bottom & 1.73 & 2.454 & -0.530 & 0.281 & -0.001 & -0.312 & 0.532 & -2.446 \\
\hline & Top & 0.00 & 3.145 & -0.693 & 0.457 & -0.017 & -0.501 & 0.697 & -3.133 \\
\hline First & --- & 0.58 & 3.148 & -0.694 & 0.457 & -0.016 & -0.502 & 0.698 & -3.136 \\
\hline Interior & $*$ & 0.67 & 3.216 & -0.705 & 0.465 & -0.019 & -0.510 & 0.709 & -3.204 \\
\hline \multirow[t]{5}{*}{ Web } & $* *$ & 0.87 & 3.215 & -0.705 & 0.465 & -0.018 & -0.510 & 0.709 & -3.202 \\
\hline & --- & 1.15 & 2.948 & -0.646 & 0.427 & -0.018 & -0.469 & 0.650 & -2.936 \\
\hline & Bottom & 1.73 & 2.935 & -0.644 & 0.429 & -0.017 & -0.470 & 0.648 & -2.924 \\
\hline & Top & 0.00 & 3.323 & -0.736 & 0.493 & -0.015 & -0.540 & 0.740 & -3.310 \\
\hline & --- & 0.58 & 3.327 & -0.737 & 0.492 & -0.014 & -0.541 & 0.741 & -3.313 \\
\hline Middle & $*$ & 0.67 & 3.406 & -0.750 & 0.503 & -0.016 & -0.551 & 0.754 & -3.392 \\
\hline \multirow[t]{3}{*}{ Web } & $* *$ & 0.87 & 3.404 & -0.750 & 0.503 & -0.016 & -0.552 & 0.754 & -3.391 \\
\hline & --- & 1.15 & 3.152 & -0.693 & 0.468 & -0.015 & -0.513 & 0.697 & -3.140 \\
\hline & Bottom & 1.73 & 3.241 & -0.691 & 0.469 & -0.015 & -0.515 & 0.695 & -3.128 \\
\hline
\end{tabular}

* Centroid of the Cross-Section of Bridge 
Table 2 Comparison with Beam Theory Solution - Maximum Longitudinal Normal Stress for the Simply Supported Box Girder Bridge

\begin{tabular}{|c|c|c|}
\hline \multirow[t]{2}{*}{ Analytical Method } & \multicolumn{2}{|c|}{$\begin{array}{c}\text { Maximum Longitudinal Norma } \\
\text { Stress in Flange (MPa) }\end{array}$} \\
\hline & Top & Bottom \\
\hline Beam Theory & -6.19 & 10.76 \\
\hline $\begin{array}{c}\text { Cheung et. al. } \\
\text { [1] }\end{array}$ & -5.25 & 8.99 \\
\hline $\begin{array}{l}\text { Proposed FSM } \\
\text { Program }\end{array}$ & -5.26 & 9.05 \\
\hline
\end{tabular}

Table 3: Comparison with Beam Theory Solution - Maximum Longitudinal Normal Stress (MPa) for the Continuous Bridge

\begin{tabular}{|c|c|c|c|c|c|c|}
\hline \multirow{2}{*}{$\begin{array}{l}\text { Type of } \\
\text { Flange }\end{array}$} & \multirow{2}{*}{$\begin{array}{l}\text { Analysis } \\
\text { Method }\end{array}$} & 1 & 2 & 3 & 4 & 5 \\
\hline & & $\begin{array}{l}\text { Mid-Span of } \\
1^{\text {st }} \text { Span }\end{array}$ & $2^{\text {nd }}$ Support & $\begin{array}{l}\text { Mid-Span of } \\
2^{\text {nd }} S p a n\end{array}$ & $3^{\text {rd }}$ Support & $\begin{array}{l}\text { Mid-Span of } \\
3^{\text {rd }} \text { Span }\end{array}$ \\
\hline & $\begin{array}{l}\text { Beam } \\
\text { Theory }\end{array}$ & -5.42 & ---------- & -4.06 & --------- & -5.39 \\
\hline Top Flange & $\begin{array}{l}\text { Model } 3 \\
\text { Percentage } \\
\text { Difference }\end{array}$ & $\begin{array}{l}-4.50 \\
17.0\end{array}$ & -------- & $\begin{array}{l}-3.53 \\
13.1\end{array}$ & --------- & $\begin{array}{l}-4.48 \\
16.9\end{array}$ \\
\hline Bottom & $\begin{array}{l}\text { Beam } \\
\text { Theory }\end{array}$ & 7.82 & --------- & 5.86 & --------- & 7.78 \\
\hline Flange & $\begin{array}{l}\text { Model } 3 \\
\text { Percentage } \\
\text { Difference }\end{array}$ & $\begin{array}{l}7.16 \\
8.4\end{array}$ & --------- & $\begin{array}{l}5.62 \\
4.1\end{array}$ & -------- & $\begin{array}{l}7.12 \\
8.5\end{array}$ \\
\hline
\end{tabular}

\section{DISCUSSION OF STRESS DISTRIBUTION}

The stress distributions are presented in Figures 10 18 and Table 1.

\subsection{Twisting Moment}

This is caused by the eccentricity of loading. However, on account of the symmetry of loading the results of the twisting moment are negligible and so it is not presented.

\subsection{Longitudinal Bending Moment}

The bending moments which cause flexure in the longitudinal vertical plane is referred to as the longitudinal bending moments and this longitudinal direction mainly corresponds to the direction of traffic flow. Figures 10 and 11 show the longitudinal distribution of longitudinal bending moments at top and bottom flanges respectively, along the bridge centerline. The value of longitudinal bending moment distribution in the longitudinal section along the bridge centerline at top flange is about twice that of the bottom flange. Very high negative moments are recorded at supports while lower positive values, about $50 \%$ of that of the support are recorded at midspans.

\subsection{Transverse Bending Moment}

The bending moments in the direction perpendicular to the flow of traffic is defined as transverse bending moments. Figures 17 and 18 show the transverse distributions of transverse bending moment at crosssections through the mid-point $1^{\text {st }}$ and $2^{\text {nd }}$ spans respectively. The values of the transverse bending moment distribution at top flange are higher than the bottom flange equivalent. It is noteworthy that joint equilibrium of moments is maintained in the transverse distribution of transverse bending moments.

\subsection{Longitudinal Normal Stress}

Longitudinal Normal Stress Distribution is one of the most important stress distributions in the analysis of bridges. Figures 12 and 13 show the longitudinal distribution of Longitudinal Normal Stress at top and bottom flanges respectively, along the bridge centerline. Positive values of the longitudinal normal stress at the spans of the bottom flange indicate a state of tension while the negative values at the spans of the top flange indicate compression. Accordingly, the longitudinal normal stresses at the top flange supports indicate tension because of their positive 
values while that of the supports of the bottom flange indicate compression because of their negative values. Figures 14 and 15 show the transverse distribution of Longitudinal Normal Stress at cross-sections through the mid-point of $1^{\text {st }}$ and $2^{\text {nd }}$ spans respectively. It is noteworthy that the Longitudinal Normal Stress distribution across the flange width is not uniformly distributed in the spans. It has peak values at the web/flange joints and lowest values at the flange remote from the joint. This is quite different from the beam theory solution which portrays uniform longitudinal normal stress distribution across the flange width.

\subsection{Transverse Normal Stress}

Figure 16 shows the transverse distribution of transverse normal stress at cross section through the mid-point of $1^{\text {st }}$ span. Generally speaking, the values of the transverse normal stress distribution are much smaller than that of longitudinal normal stress distribution.

\subsection{Shear Stress Distribution in Webs}

The bending moment is resisted mainly by flanges and the shear stress is resisted mainly by the webs. Table 1 shows that the shear stress is maximum at the end supports and reduces in value towards the interior. In general, the shear stress distribution is a maximum at the centroid of the bridge cross-section. So the maximum shear stress occurred at the centroid of the bridge in the Middle Web over the cross-section through the $1^{\text {st }}$ end support

\section{COMPARISON OF RESULTS WITH BEAM THEORY SOLUTION}

In Table 2 the peak stresses obtained by both Cheung et al. [1] and the developed program, is less than the beam theory solution for the simply supported box girder bridge. This is also true in Table 3 where the peak stresses obtained by the developed program (i.e. finite strip solution) are slightly less than the beam theory solutions for the continuous multi-cell thinwalled box girder bridge. These peak stress values occur at the web/flange joints where there is high stress concentration.

\section{CONCLUSION}

This research study, principally, investigated stress distribution in continuous thin-walled multi-cell box girder bridges, using a MATLAB program developed by the authors for the finite strip analysis of continuous thin-walled box girder bridges. The beam theory solution was used as the benchmark in the analytical studies. The program was first used to determine stress distributions in a simply supported box girder bridge subjected to eight point loads and the results obtained compared favorably with literature. Next, a numerical study on stress distributions was carried out on a continuous thinwalled multi-cell box girder bridge. Based on the results of analysis the following remarks are made: The longitudinal normal stress distribution across the flange width is not uniformly distributed in the spans. It has peak values at the web/flange joints and lowest values at the flange remote from the joint. This is quite different from the beam theory solution which portrays uniform longitudinal normal stress distribution across the flange width. The effects of transverse normal stress and twisting moment are negligible. Shear stress is maximum at the end supports and reduces in value towards the interior. The shear stress distribution is a maximum at the centroid of the bridge cross-section. So the maximum shear stress occurred in the Middle Web, at the centroid of the bridge, over the cross-section through the $1^{\text {st }}$ end support. Joint equilibrium of moments is maintained in the transverse distribution of transverse bending moments.

The effects of shear deformation are included in the finite strip analysis while the beam theory solution neglects the effect of shear deformation. It can be inferred that, unlike the beam theory solution, classical finite strip can effectively be used to determine stress distributions in continuous thinwalled multi-cell box girder bridges; however it underestimates peak stress values at points of high stress concentration. This shortcoming could be remedied by applying spline finite strip method.

Compared to other methods used in the analysis of thin-walled box girder bridges, the finite strip method is more straightforward, less complicated and more easily lends itself to programming. MATLAB software proved to be very efficient in this work. The MATLAB commands and the built-in functions are well suited for the analytical processes in finite strip method. In the application of the MATLAB program to finite strip analysis of thin-wall box girder bridges, it is easy to specify those locations at which responses are required and then the computations follow accordingly.

It can be concluded that under symmetrical loading the longitudinal normal stress, shear stress at end 
supports, transverse bending moment, and longitudinal bending moment are substantial while the transverse normal stress and twisting moment are negligible. The program and the principles presented in this work can be used, in practice, to study stress distributions in simply supported thin-walled box girders, continuous thin-walled multi-cell box girder bridges, as well as thin-walled box beams and prismatic folded plates.

\section{REFERENCES}

1. Cheung, M. S., Li, W. and Chidiac, S. E. (1996), Finite Strip Analysis of Bridges, $1^{\text {st }}$ Ed., E \& FN SPON, London.

2. Cheung, Y.K. (1976), Finite Strip Method in Structural Analysis, $1^{\text {st }}$ ed., Pergamon Press, Oxford.

3. Choi, C. K., Kim, K. H. and Hong, H. S. (2002), Spline Finite Strip Analysis of Prestressed Concrete BoxGirder Bridges, Engineering Structures, Vol.24, pp. $1575-1586$.

4. Davidson, J. S., Abdalla, R. S. and Madhavan, M., (2004), Stability of Curved Bridges During Construction, University Transportation Center of Alabama (UTCA), UTCA Report No. 03228, University of Alabama.

5. Dong, J., and Sause, R. (2010), Finite Element Analysis of Curved Steel Girders With Tubular Flanges, Engineering Structures, Vol. 32, pp.319327.

6. Ezeokpube, G. C. (2013). Finite Strip Analysis of Continuous Thin-Walled Box girder Bridges, PhD Thesis, University of Nigeria Nsukka (UNN).

7. Fan, Z. T., and Helwig T. A. (1999). Behaviour of steel box girders with top flange bracing, Journal of Structural Engineering, American Society of Civil Engineers, 125(8), New York NY, pp. 829-837.

8. Fu, K. C., Lu, F. (2003), Nonlinear Finite-Element Analysis for Highway Bridge Superstructures, J. of Bridge Engineering, 8(3), pp. 173-179.

9. Halkude, S. A. and Akim, C. Y. (2012), Analysis of Straight and Skewed Box Girder Bridge by Finite
Strip Method, International J. of Emerging Technology and Advanced Engineering, (IJETAE), 2(11), pp. 191-198.

10. Kurian, B. and Menon, D. (2007), Estimation of Collapse Load of Single Cell Concrete Box-Girder Bridges, J. of Bridge Engineering, 12 (4), pp. 518526.

11. Lertsima, C., Chaisomphob, T., and Yamaguchi, E., (2004), Stress Concentration Due to Shear Lag in Simply Supported Box Girders, Engineering Structures, Vol. 26, pp. 1093-1101.

12. Luo, Q. Z., Tang, J. and Li, Q. S. (2003), Calculation of Moment on Top Slab in Single-Cell Box Girders, J. of Structural Engineering, 129 (1), pp. 130-134.

13. Ovesy, H. R, Ghannadpour, S. A. M., and Zia-Dehkordi, E. (2013), Buckling Analysis of Moderately Thick Composite Plates and Plate Structures Using an Exact Finite Strip, Composite Structures, Vol. 95, pp. 697704.

14. Rockey, K. C., Evans, H. R., Griffiths D. W. and Nethercot, D, A., (1983). The Finite Element Method (A Basic Introduction), $2^{\text {nd }}$ ed., Mackays of Chatham Ltd., Great Britain.

15. Sa-nguanmanasak, J., Chaisomphob, T., and Yamaguchi, E., (2007), Stress Concentration Due to Shear Lag in Continuous Box Girders, Engineering Structures, Vol.29 (7), pp. 1414- 1421.

16. Sennah, K. M. and Kennedy, J. B. (2001), State-of-theArt in Design of Curved Box-Girder Bridges, J. of Bridge Engineering, 6 (3), pp.159-166.

17. Song, S. T., Chai, Y. H. and Hida, S .E. (2003), LiveLoad Distribution Factors For Concrete Box-Girder Bridges, J. Bridge Engineering, 8, (5), pp.273-280.

18. Vlazov, V. Z. (1965), "Thin-walled elastic beams" OTS61-11400, National Science Foundation, Washington, D.C.

19. Yamaguchi, E. (2008). Stress Concentration and deflection of simply supported box girder including shear lag effect, Structural Engineering and Mechanics, 28(2), pp. 207-220. 